Oncology 1986;43:I-V

\title{
Contents, Vol. 43, 1986
}

\section{Vol. 43, 1986}

ONCOLOGY

International Journal of Cancer Research and Treatment

Founded 1948 as 'Oncologia' by H.R. Schinz Continued by V. Richards 1967-1975

Editors

S. Eckhardt, Budapest K. Munk, Heidelberg -G.P. Murphy, Buffalo, N.Y. H. Sugano, Tokyo H.

Wrba, Wien

Editorial Board

S. Barg, Buenos Aires

N.N. Blokhin, Moscow

M.M. Burger, Basel

G. Delia Porta, Milan

H. Endo, Fukuoka

J.F. Fraumeni, Jr., Bethesda, Md.

S. Garattini, Milan

D.G. Harnden, Manchester

W.H. Hartmann, Nashville, Tenn.

D.K. Hossfeld, Hamburg

A. Junqueira, Sao Paulo

A.S. Ketcham, Miami, Fla.

E. Klein, Stockholm

T. Koszarowski, Warszawa

C. Lagarde, Bordeaux

P.N. Magee, Philadelphia, Pa.

D. Metcalf, Melbourne, Vic.

G. Nagel, Gottingen

N.P. Napalkov, Leningrad C.L.M. Olweny, Kampala J.E. Ospina, Bogota W.E. Powers, Detroit, Mich. St. Tanneberger, Berlin L. Tomatis, Lyon

S. Karger • Medical and Scientific Publishers • Basel $\mathbf{a}$ Miinchen • Paris • London • New York • New Delhi • Singapore $\mathbf{a}$ Tokyo $\bullet$ Sydney

Drug Dosage

The authors and the publisher have exerted every effort to ensure that drug selection and dosage set forth in this text are in accord with current recommendations and practice at the time of publication. However, in view of ongoing research, changes in government regulations, and the constant flow of information relating to drug therapy and drug reactions, the reader is urged to check the package insert for each drug for any change in indications and dosage and for added warnings and precautions. This is particularly important when the recommended agent is a new and/or infrequently employed drug.

All rights reserved. 
No part of this publication may be translated into other languages, reproduced or utilized in any form or by any means, electronic or mechanical, including photocopying, recording, microcopying, or by any information storage and retrieval system, without permission in writing from the publisher or, in the case of photocopying, direct payment of a specified fee to the Copyright Clearance Center (see 'Information for Readers and Subscribers').

(C) Copyright 1986 by

S. Karger AG, P.O. Box. CH-4009 Basel (Switzerland) Printed in Switzerland by Graphische Anstalt Schiiler AG, Biel

Contents Vol. 43,1986

No. 1

No. 2

Original Paper

Age at First Birth, Dietary Practices and Breast Cancer Mor tality in Various Italian Regions

La Vecchia, C; Pampallona, S 1

Hormonal Changes during a Prolonged Tamoxifen Treatment

in Patients with Advanced Breast Cancer

Szamel, I.; Vincze, B.; Hindy, I.; Hermann, I.; Borvendeg,

J.; Eckhardt, S 7

Hexamethylmelamine, Cyclophosphamide, Adriamycin, cis-Platinum Chemotherapy as Initial and Second-Line Treatment of Advanced Ovarian Carcinoma Richman, CM.; Podczaski, E.; Weiser, P.A.; Herbst, A.L. 12

Aclacinomycin A and Behenoyl Arabinofuranosylcytosine Combination Chemotherapy for Previously Untreated

Acute Leukemia

Sampi, K.; Sakurai, M.; Kaneko, Y.; Hattori, M 18

Leukocyte Adherence Inhibition Assay in the Diagnosis and

Follow-Up of Colorectal Cancer Patients

Weisman, Z.; Shani, A.; Fink, A.; Shindel, A.; Sela, A.;

Wechsler, U.; Pfeffermann, R.; Bentwich, Z 23

Single, High-Dose Intravenous Dexamethasone as an Antiemetic in Cancer Chemotherapy Zaglama, N.E.; Rosenblum, S.L.; Sartiano, G.P.; Brady, M.; Gonzalez, M.F.; Valdivieso, J.G 27

Hypoalbuminemia in Patients Receiving Cisplatin: Correla

tion between Liver Platinum and Decrease in Serum Al

bumin

Nanji, A.A.; Mikhael, N.Z.; Stewart, D.J 33

Comparative Study of Wdsley-RAS Oncogene Expression with Conventional Clinicopathologic Parameters of Breast Cancer

Agnantis, N.J.; Parissi, P.; Anagnostakis, D.; Spandidos,

D.A. 36

Assessment of the Human Tumor Cloning Assay for Urologic

Malignancies with Special Emphasis on Bladder Cancer

Dittrich, C; Schmidbauer, C.P.; Havelec, L.; Lenzhofer,

R.; Breyer, S.; Porpaczy, P.; Moser, K 
Interactions of Cytotoxic and Other Drugs: Rapid Cell Culture

Assay

Sauter, C; Cogoli, M.; Arrenbrecht, S

46

Nitrate and Nitrite in Normal Gastric Juice. Precursors of the

Endogenous N-Nitroso Compound Synthesis

Mueller, R.L.; Hagel, H.-J.; Wild, H.; Ruppin, H.;

Domschke, W 50

Optimization of the Production of hCGP-Like Material by CaSki Human Cervical Carcinoma

Cells in Roller Bottle Culture

Hussa, R.O.; Pattillo, R.A.; Ruckert, A.C.F.; Rinke, M.L.;

Cortesi, J.P.; Fein, H.G

54

Cellular Pharmacology of Doxorubicin in Sensitive and Resis

tant Rat Glioblastoma Cells in Culture

Vrignaud, P.; Londos-Gagliardi, D.; Robert, J

60

Book Reviews

67

Original Paper

Pain Killing with Calcitonin in Patients with Malignant Tumours

Szanto, J.; Jozsef, S.; Rado, J.; Juhos, E.; Hindy, I.; Eck

hardt, $S$

69

Controlled Phase HI Clinical Study of 4-Epi-Doxorubicin +

5-Fluorouracil versus 5-Fluorouracil Alone in Metastatic

Gastric and Rectosigmoid Cancer

Kolaric, K.; Potrebica, V.; Stanovnik, M 73

Phase I Study of C/s-Dichloro-7ra«.?-Dihydroxy-Bis(Isopropy-

lamine)Platinum IV (CHIP).

Ribaud, P.; Gouveia, J.; Misset, J.L.; Mathe, G 78

Phase II Trial of High-Dose Continuous Infusion 5-Fluoroura

cil with Allopurinol Modulation in Colon Cancer

Ahmann, F.R.; Garewal, H.; Greenberg, B.R 83

Determination of 7-Hydroxymethotrexate in Human Plasma

by Reversed Phase High-Performance Liquid Chroma

tography

Erttmann, R.; Bielack, S.; Landbeck, G 86

Testicular Seminoma: Results of Treatment at the Northern Israel Oncology Center Stein, M.;

Steiner, M.; Koten, A.; Cohen, Y.; Robinson, E. 89

Natural Killer and Antibody-Dependent Cell-Mediated Cyto

toxicity Activities and Large Granular Lymphocyte Fre

quencies in Viscum album-Treated Breast Cancer Patients

Hajto, T.; Lanzrein, C 93

Inhibitory and Stimulatory Effects of Dianhydrogalactitol, an

Alkylating Cytostatic Agent on the Humoral Immune Re

sponse

Gero, E.; Gaal, D 98

Secondary Malignant Lesions of the Heart and Pericardium in

Neoplastic Disease

Skhvatsabaja, L.V 
Gastric Non-Hodgkin's Lymphoma after Successful Treat

ment of Hodgkin's Disease

Eridani, S.; Singh, A.K

Differential Count of 5,000 Leukocytes for Acute Nonlympho-

cytic Leukemia Patients during Remission

Masaoka, T.; Takubo, T.; Kubota, Y.; Oguma, S.; Tanaka,

T.; Ueda, T.; Nakamura, H.; Shibata, H.; Yoshitake, J.;

Senda, N 110

Environmental Factors and Cancer Mortality in Italy: Correla

tional Excercise

Decarli, A.; La Vecchia, C 116

Inhibition of the Specific Binding of 12-O-Tetra-decanoyl-

phorbol-13-Acetate to Mouse Epidermal Membrane Frac

tions by Glycyrrhetic Acid

Kitagawa, K.; Nishino, H.; Iwashima, A 127

Berberine Sulfate Inhibits Tumor-Promoting Activity of Tele-ocidin in Two-Stage

Carcinogenesis on Mouse Skin Nishino, H.; Kitagawa, K.; Fujiki, H.; Iwashima, A. ... 131

Book Reviews $\quad 135$

Announcement $\quad 136$

IV

Contents

No. 3

No. 4

Original Paper

Managing Minimal Residual Malignant Disease

Mathe, G.; Reizenstein, P 137

Circulating Immune Complexes in Malignant Melanoma: Serial Studies in 130 Patients

Bharwani, N.; Campbell, L.; Ashley, P.; Queen, W.D.; Phil

lips, T.M.; Jerry, L.M 143

Evaluation of Carcinoembryonic Antigen Levels in Gastric Juice, Stomach Mucosa and Plasma

in High-Risk and Gastric Cancer Patients

Castelli, M.; Guadagni, S.; Bagnato, A.; Pistoia, M.A.; Car-

boni, M.; Sega, E 149

Changes in Peripheral Lymphocyte Subsets during Radiotherapy for Lung Cancer Patients

Ogawa, Y.; Maeda, T.; Seguchi, H.; Yoshida, S.; Inomata,

T.; Hamada, F 154

Functional Activities of Enriched Fc Receptor Bearing T Lym

phocytes in Hodgkin's Disease

Gulwani, B.N.; Advani, S.H.; Gangal, S.G 159

Acute Leukemia after Treatment for Ovarian Cancer. Report

of Four Cases and Review of the Literature

De Gramont, A.; Remes, P.; Krulik, M.; Smadja, N.; Dro-

let, Y.; Donadio, D.; Louvet, C; Brissaud, P.; Sirinelli, A.;

Dray, C; Debray, J 165 
High-Dose Metoclopramide and Dexamethasone as an Antiemetic in Chemotherapy of Breast Cancer Gez, E.; Goodman, S.; Isacson, R.; Gerra, C; Sulkes, A. . 173

Prognostic Significance of Functional Defects of Granulocytes in Myeloproliferative Disease

Mazzone, A.; Ricevuti, G.; Rossi, M.; Rizzo, S.C 176

Inhibition of the Binding of 7,12-Dimethylbenz[a]anthracene

to DNA by Ascorbic Acid, Reduced Glutathione and Cys

teine in Chick Embryo Cells Cultured in vitro

Liotti, F.S.; Bodo, M.; Pezzetti, F.; Guerrieri, P.; Menghini,

A.R 183

Chemotherapy-Induced Malignancies in Rats after Treatment

with Cisplatin as Single Agent and in Combination: Pre

liminary Results

Kempf, S.R.; Ivankovic, S 187

Failure to Boost the Increased Clearance of Embolic Tumor

Cells from the Lung with Dose Scheduling: Corynebacte-

rium parvum Studies

Proctor, J.W.; Yamamura, Y 192

Three Alkaloids as Selective Destroyers of Cancer Cells in

Mice. Synergy with Classic Anticancer Drugs

Beljanski, M.; Beljanski, M.S 198

Book Reviews 204

Original Paper

Phase II Study of AMSA and Doxorubicin to Treat Metastatic Breast Cancer

Casimir, M.T.; Buzdar, A.U.; Blumenschein, G.R.; Horto-

bagyi, G.N.; Bodey, G.P 205

Elevated Plasma Levels of Beta-Thromboglobulin in Breast Cancer

Benedetti Panici, P.; Scambia, G.; Massidda, B.; Chessa,

P.; Tarquini, A.; Mancuso, S 208

Comparison of Oral Ftorafur and Intravenous 5-Fluorouracil

in Patients with Advanced Cancer of the Stomach, Colon

or Rectum

Bjerkeset, T.; FJ0sne, H.E 212

Failure of Allopurinol to Provide Clinically Significant Protec

tion against the Hematologic Toxicity of a Bolus 5-FU

Schedule

Garewal, H.; Ahmann, F.R 216

Paroxysmal Supraventricular Tachycardia during Treatment

with Cisplatin and Etoposide Combination

Fassio, T.; Canobbio, L.; Gasparini, G.; Villani, F 219

Adjuvant Chemotherapy in Ocular Malignant Melanoma. Study of 20 Cases

Sellami, M.; Weil, M.; Dhermy, P.; Aron-Rosa, D.; Jacquil-

lat, C 221

Demonstration of Epstein-Barr Virus in Malignant Non-Hodg-kin's Lymphomas

Wutzler, P.; Farber, I.; Sauerbrei, A.; Helbig, B.; Wutke, K.; Rudiger, K.-D.; Scheibner, K.;

Bfichacek, B.; Vonka, V. . 224 
Malignant Fibrous Histiocytoma Associated with Peripheral Blood Eosinophilia. In vitro Studies Demonstrating Tumor-Derived Eosinophilopoietic Activity Serke, S.; Brenner, M.;

Zimmermann, R.; Lobeck, H. . . 230

Accumulation of ulIn-Bleomycin in Metastatic Lesions from

Carcinoma of the Uterine Cervix and the Ovary

Kida, T.; Ikeda, M 234

Quantitative Changes in Surface Immunoglobulin Expression

in WEHI-231 Lymphoma Cells in Relation to Their Prolif

erative Rate

Mujagic, H.; Shackney, S.E.; Smith, C.E.; Chen, S.S.

Primary Intestinal Lymphoma in Iraqi Children

Al-Bahrani, Z.; Al-Mondhiry, H.; Al-Saleem, T.; Zaini, S. 243

Estrogen Receptor from Human Breast Cancer and from Nor

mal Human Uterus: Isolation and Characterization of Sim

ilar Binding Complexes

Bezwoda, W.R.; Mansoor, N

Different Sensitivity of Two Walker 256 Carcinoma Lines to Cyclophosphamide: Correlation with Drug Distribution, Biotransformation and Macromolecule Binding Donelli, M.G.; Guaitani, A.; Torti, L.; Damia, G.; Corti, F.; Bianchi, M.; Tortoreto, M.; Pantarotto, C; Bartosek, I. 257 Inhibition of Endogenous Respiration in Rat Heart Slices as a

Measure of Mitoxantrone Cardiac Toxicity

Neri, B.; Cini-Neri, G 264

Effect of Cholic Acid on Tumor in the Egyptian Toad

Sadek, LA 268

Book Reviews

271

Contents

$\mathrm{V}$

No. 5

No. 6

Original Paper

Recovery of Blood and Bone Marrow Stem Cells following Intense Chemotherapy and Autologous Bone Marrow Transplantation

Thomas, M.R.; Robinson, W.A.; Mughal, T.I.; Morton, N.;

Glode, L.M 273

Survival of Patients with Relapsing Breast Cancer: Analysis of 302 Patients

Lionetto, R.; Pronzato, P.; Bertelli, G.F.; Ardizzoni, A.;

Conte, P.F.; Rosso, R 278

Analgetic Activity of Calcitonin in Patients with Painful Os

teolytic Metastases of Breast Cancer. Results of a Con

trolled Randomized Study

Roth, A.; Kolaric, K 283 
Treatment of Advanced Measurable Gastric Carcinoma with 5-Fluorouracil, Adriamycin, and BCNU Lopez, M.; Di Lauro, L.; Papaldo, P.; Conti, E.M.S. ... 288

Maintenance of Antiemetic Effect of a Metoclopramide-Dexa-methasone Combination during Subsequent Cisplatin Courses

Cognetti, F.; Carlini, P.; Pinnaro, P.; Ruggeri, E.M.; Capo-

rali, C 292

Primary Multiple Colonic Carcinoma

Frass, M.; Lochs, H.; Potzi, R.; Dragosics, B.; Ferenci, P.;

Pesendorfer, F.X.; Holzner, J.H 295

Local Microwave Hyperthermia in the Treatment of Carcinoma of the Prostate

Yerushalmi, A.; Shani, A.; Fishelovitz, Y.; Arielly, J.; Singer, D.; Levy, E.; Katsnelson, R.;

Rakowsky, E.; Stein, J.A. 299

Value of Serum Alpha-Fetoprotein and Ferritin in the Diagnosis of Hepatocellular Carcinoma

Tatsuta, M.; Yamamura, H.; Iishi, H.; Kasugai, H; Okuda, S. 306

Elevated Pancreatic Oncofetal Antigen Levels Measured by Enzyme Immunoassay in Pure

Pancreatic Juice of Patients with Pancreatic Cancer Nishida, K.; Yoshikawa, T.; Fukumoto, K.;

Kondo, M. .311

Serum Immunoglobulin Levels in Patients with Head and

Neck Cancer (IgE, IgA, IgM, IgG)

Vinzenz, K.; Pavelka, R.; Schonthal, E.; Zekert, F 316

Curve Models for Comparative Phase III Trials: Heterogeneity

of the Population

Eriguchi, M.; Mathe, G

Diagnostic Value of the Computerized Tube Leukocyte Adherence Inhibition (LAI) Assay for

Human Colorectal, Breast and Lung Cancers

Berner, Y.; Fink, A.; Shani, A.; Weisman, Z.; Eliraz, A.;

Bruderman, I.; Bentwich, Z 327

Preventive Effect of Vitamin C (L-Ascorbic Acid) on Methyl-

cholanthrens-Induced Soft Tissue Sarcomas in Mice

Abdel-Galil, A.M 335

Books Received $\quad 338$

Book Reviews $\quad 339$

Announcement $\quad 322$

Original Paper

Phase II Trial of 4'-Epidoxorubicin in Advanced Gastrointestinal Tumor Shiu W.; 'O', S.K.;

Tsao, S.Y.; Woo, K.S.; Martin, C. . . 341

Further Studies on the Antineoplastic Activity of Homo-Aza-Steroidal Esters Pairas, G.;

Catsoulacos, P.; Papageorgiou, A.; Boutis, L. . 344

Corticosteroid Responsive Immune Thrombocytopenia in Hodgkin's Disease Sonnenblick, M.;

Kramer, M.R.; Hershko, C. 349

Incidence of Hematopoietic Malignancies in a Weil-Defined Population in France Carli, P.M.;

Milan, C; Lorenzini, J.L.; Guy, H.; Michiels, R. 354

Cytogenetic Studies in Secondary Leukemia: Statistical

Analysis

De Braekeleer, $\mathrm{M} \quad 358$

Glial Fibrillary Acidic Protein in Brain Tumors 
Luevano, E.; Tena, M.; Zamora, A.; Sotelo, J

Transforming Activity of DNA Extracted from BKV-Transformed Hamster Cells after Passages in Culture

Possati, L.; Collesi, A.; Rosciani, C; Rubini, C

Cure Rates and Tumor Resistance in Cured Mice after Nitro sourea Treatment of EMT6 Ascites Tumors

Feola, J.M.; Maruyama, Y 372

Chemotherapeutic Effects of 13 Nitrosoureas on the LSA Lym

phoma Ascites Tumor of the C57BL Mouse

Feola, J.M.; Maruyama, Y 378

Proliferative Activity of Human Solid Tumors Evaluated by Thymidine Labeling Index and Primer-Dependent a-DNA Polymerase

Alama, A.; Conte, P.F.; Di Marco, E.; Favoni, R.E.; Nico-

lin, A 385

Synthesis of a New Nor-Aza-Steroidal Ester of p-N, N-bis-(2-Chloroethyl)aminophenylbutyric Acid and in vitro Study of Its Mutagenicity and Clastogenicity Athanasiou, C; Pairas, G.;

Catsoulacos, P.; Athanasiou, K. 390

Books Received 395

Book Reviews 396

Author Index 401

Contents Vol. 43 after 402

Suppl. 1

Mistletoe

Pharmacologically Relevant Components of Viscum Album L. 